\title{
Tuberculous abscess on the chest wall
}

\author{
S. Ayık, A. Çakan, N. Aslankara, A. Özsöz
}

ABSTRACT: Tuberculous abscess on the chest wall. S. Ayık, A. Çakan, N. Aslankara, A. Özsöz.

A 58-year old patient on dialysis for four years due to chronic renal failure presented with complaints of painless, continuously growing swelling on the left of his back and coughing, symptoms evolving over a period of approximately 3 months. Physical examination revealed a soft fixed mass of $10 \times 10 \times 4 \mathrm{~cm}$ on the left infrascapular area on the chest wall. The sample taken from the inflammation on the chest wall was analyzed with PCR method which resulted positive for Acid Fast Bacilli (AFB), tissue biopsy showed dermatitis with granulomata and sputum was positive for AFB. Thoracic MR, performed for the purpose of detecting the relationship between the lesion on the lung and the one on the chest wall, detected changes in the inflammatory soft tissues and multiple small abscess formations on the chest wall. There was no pathological signal in the bone structures of the chest wall. This case underlines the necessity to include "Empyema necessitatis" in the preliminary diagnosis when there is a soft tissue swelling on the chest wall without inflammatory signs in patients with reduced immune defences.

Monaldi Arch Chest Dis 2009; 71: 1, 39-42.

Keywords: Empyema necessitatis, Tuberculous abscess, Chest wall, Tuberculosis.

Department of Chest Disease, Izmir Chest Diseases and Thorasic Surgery Centre, Izmir, Turkey.

Correspondence: Ayik S, Department of Chest Disease, Izmir Chest Diseases and Thorasic Surgery Centre, Izmir, Turkey; e-mail:aydancakan@yahoo.com

\section{Introduction}

Although there has been a reduction in the prevalence of tuberculosis in the general population of developed countries, it is still high in individuals with reduced immune resistance. In addition, tuberculosis may present with clinical and radiological atypical findings in this group of patients. In cases of chronic renal failure, impairing both cellular and humoral immunity, the risk of infection can be 6.9-52.5 times higher than that of the normal population [1].

Soft tissue tuberculosis of the chest wall generally develops from the bone, joint or pleural tuberculosis through neighbourhood exposure or from chest wall lymphadenitis through direct spread $[2,3]$. Although it is common that lesions spread towards the peripheral soft tissue and form cold abscess in the vertebrae, spread of these cold abscesses towards chest wall (Empyema necesitasis) is not common $[4,5]$.

This article presents a case of chronic renal failure with progressive development of cold abscess of the chest wall.

\section{Case Report}

A 58-year old patient who was on dialysis for four years due to chronic renal failure presented with complaints of painless, continuously growing swelling on the left of his back and coughing, symptoms evolving over a period of approximately 3 months. His history showed that he has been undertaken dialysis for 4 years due to chron- ic renal failure. There was no history of other diseases.

Physical examination revealed a soft fixed mass of $10 \times 10 \times 4 \mathrm{~cm}$ on the left infrascapular area on the chest wall and the presence of a lateral incision approximately $2 \mathrm{~cm}$ lower than the mass with serous inflammatory secretions originating from this incision (figure 1).

It was discovered that the excision was performed one week before and that pathological analysis of the material reported the presence of dermatitis with granulomata. The sample taken from the inflammation on the chest wall was analyzed with PCR method which resulted positive for Acid Fast Bacilli (AFB), tissue biopsy showed dermatitis with granulomata and sputum analysis was positive for AFB.

Chest-X-ray is shown in figure 2 and the samples from the sections of the computerized tomography (CT) of the chest are presented in figure 3. Thorax magnetic resonance imaging (MRI), performed in order to detect the relationship between the lesion and chest wall and costas, revealed a T2 high signal and a T1 low signal at the scapula medial section, paramagnetic area, shining changes of inflammatory soft tissue and formations of multiple small abscess formations in it. This lesion originated from the 3rd back costa level in the proximal and continued towards the area caudalis. The paramagnetic field seen in the apical section of the left lung, the parenchimal fibro-productive lesion and the lesion defined at the anterior wall of the chest start approximately at the same level. This underlines the possibility of intercostal infection of 


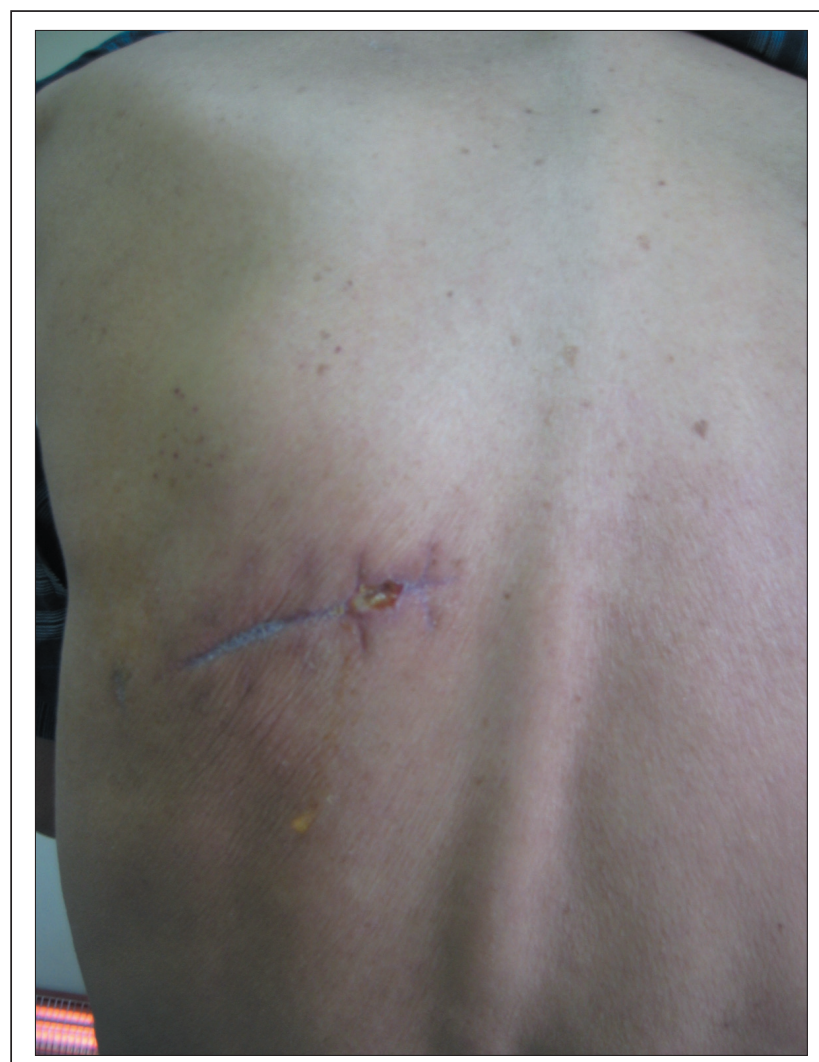

Fig. 1. - Physical examination revealed that a soft fixed mass of 10 $\mathrm{x} 10 \times 4 \mathrm{~cm}$ on the left infrascapular area on the chest wall.

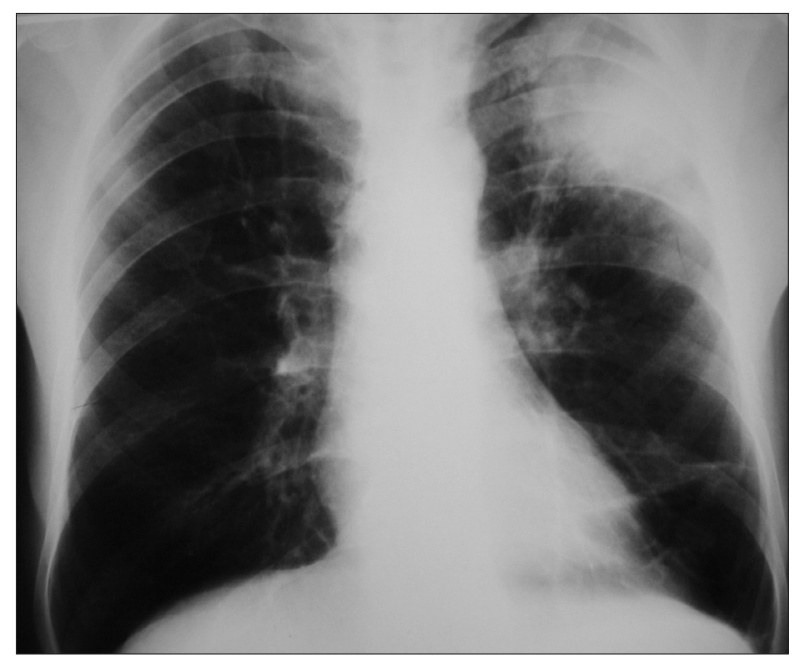

Fig. 2. - A peripheral homogenous increased density on the left upper lobe in PA chest roentgenogram.

the lesion. Pathological signal was not found in the chest wall bone structures (figure 4).

Sputum smear and the specific cultures were found positive for AFB and for M. Tuberculosis. Laboratory findings did not reveal any abnormality except for the high sedimentation rate and high level of urea and creatinin. The patient was diagnosed with active pulmonary tuberculosis and cold abscess formation on the chest wall. An anti-tubercular treatment was started with 4 drugs (Izoniasid $300 \mathrm{mg} / \mathrm{day}$, Rifampicin $600 \mathrm{mg} /$ day, Morfozinamid 2 gr/day, Ethambutol $750 \mathrm{mg} /$ day). No surgical intervention was made to the chest wall. In $6^{\text {th }}$ month of the treatment, cold abscess was totally healed (figure 5) and fibrotic changes were detected in the lung (figure 6).

\section{Discussion}

The risk of pulmonary and extra-pulmonary tuberculosis is higher in the presence of chronic renal failure, as compared with that of the general population. In these patients, clinical findings of the tubercular disease may be atyphical, generally causing delays in the diagnosis and increasing morbidity and mortality [1, 6-9]. The most frequent extra-pulmonary involvements are on pleural, peritoneal, lymphatic tissue and muscular and skeletal system [10, 11].

Development of a cold abscess on the chest wall with formation of a fistula (Empyema Necessitatis) is rare. While cold abscesses can develop from bone, pleural and parenchymal tuberculosis though direct spread [12], it can also develop without neighbourhood exposure [13, 14]. It occurs in less than $10 \%$ of the muscular and skeletal tuber-

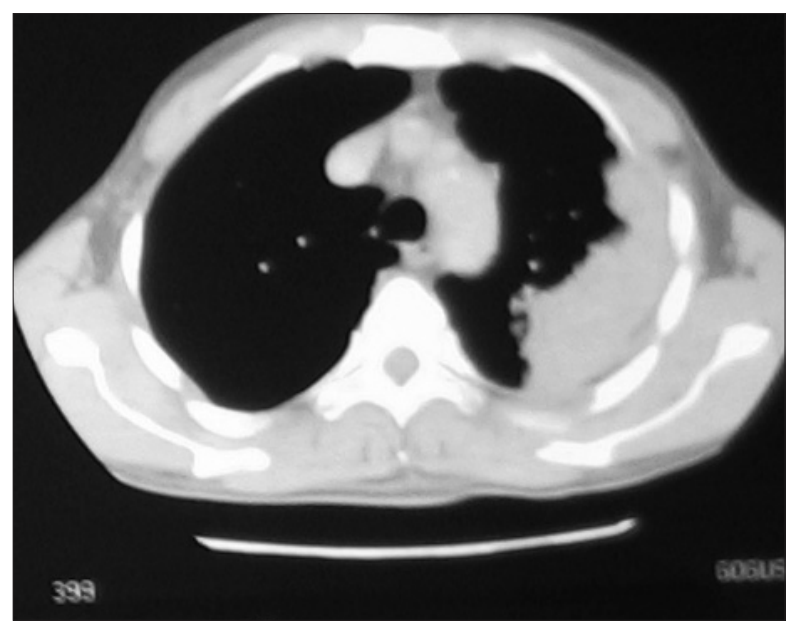

Fig. 3. - In chest CT, a peripheral parenchymal solid lesion with irregular spiculated contours which abutted the chest wall on the posterior segment of left upper lobe was identified.

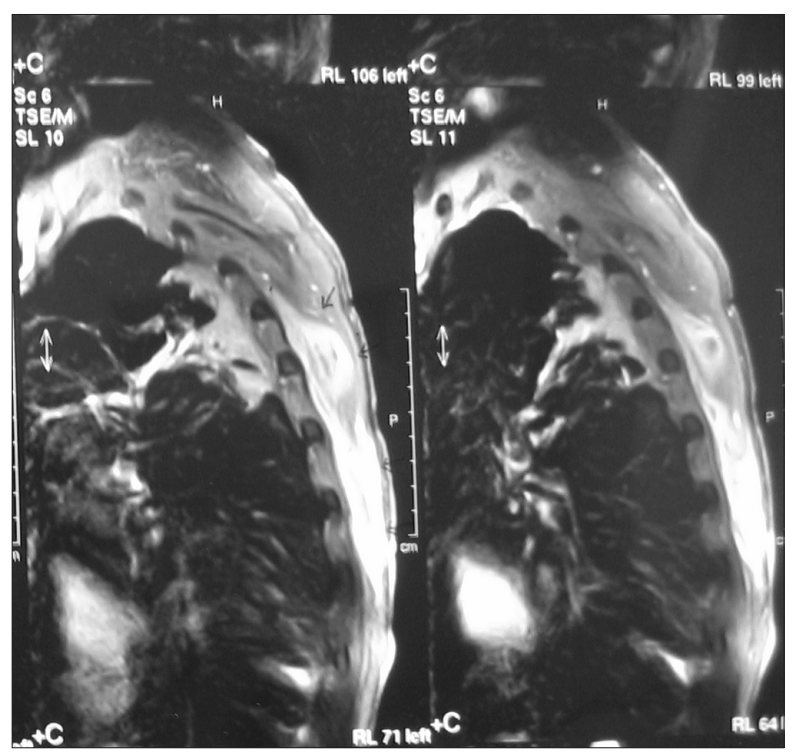

Fig. 4. - Thoracic MRI revealed the presence of inflammatory soft tissue changes showing high signal intensity on T2 and low signal intensity on T1, and displaying enhancement with paramagnetic agent administration. The parenchymal fibroproductive lesion seen on the left lung's apical zone showing enhancement with the use of paramagnetic agent and the lesion identified in the posterior chest wall both were found to begin from the same level. 


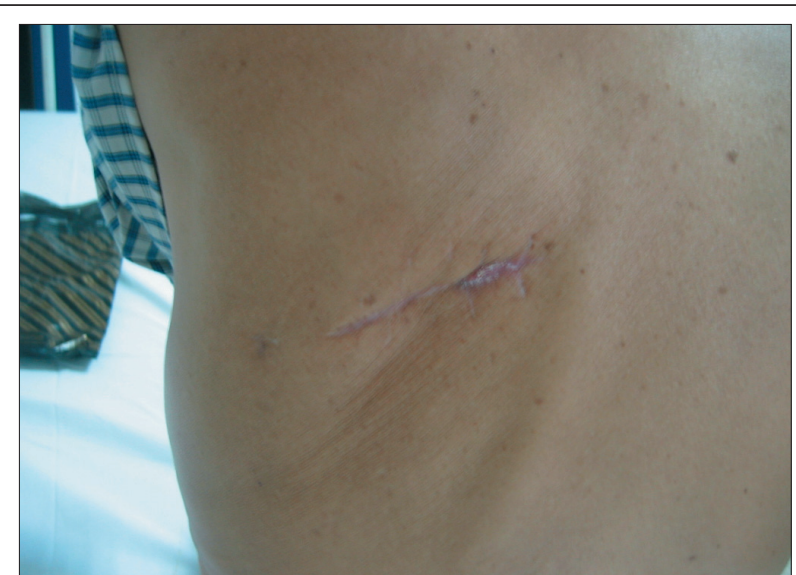

Fig. 5. - At sixth month of the therapy, clinical recovery in the cold abscess was observed.

culosis cases [15]. The incidence of pulmonary involvement accompanying to soft tissue tuberculosis is reported at the rate of $17.4-62.5 \%[16,17]$.

Reduced immune defences are a significant predisposing factor for the development of Empyema Necessitatis $[18,19]$. Empyema Necessitatis is mostly seen in the form of a soft tissue mass on the front chest wall, on the mid clavicular line and anterior axillary line [20]. However, as there is passage from the weak points on the peripheral muscular structures to the soft tissues on the pathogenesis, it may spread from intercostal area to back, from diaphragm to abdomen, retroperitoneal zone, oesophagus, breasts and neck.

We defined this abscess as a cold one due to the absence of rash and temperature increase [21, 22]. Thorax MRI findings of our case gave the impression that cold abscess on the chest wall developed from pulmonary parenchymal focus through neighbourhood exposure. The diagnosis of cold abscess on the non-fistulized chest wall is generally made on the basis of the histopathological analysis and smear of the material obtained through needle biopsy and aspiration. From several studies, culture positivity rates changing between 10 and $47 \%$ have been reported [4, 23-25]. Bacilli were detected with the PCR method of the liquid taken from the inflammation. In addition, it was found that the sputum smear was positive and M. Tuberculosis was isolated in the culture. This was the indicator of the fact that the pulmonary lesion was active.

Treatment of cold abscess on the chest wall is a very controversial subject. Most of the studies reported successful results and recommended 6 to 12 month medical treatment alone $[2,26]$. However, medical treatment may be insufficient in the case of tuberculosis as resistance develops fast in cases of tuberculosis and penetration of the anti-tuberculosis drugs to the pleural cavity is low [27]. Thus surgical drainage is indispensable. However, even after the drainage, shrunk lung may not expand. It is reported that treatment combined with surgical intervention may be useful in cases with costal involvement, particularly in terms of the decrease of recurrence and resistance against medication [16]. Surgical recommendations are recurrent abscess aspirations, abscess excision and primer closing
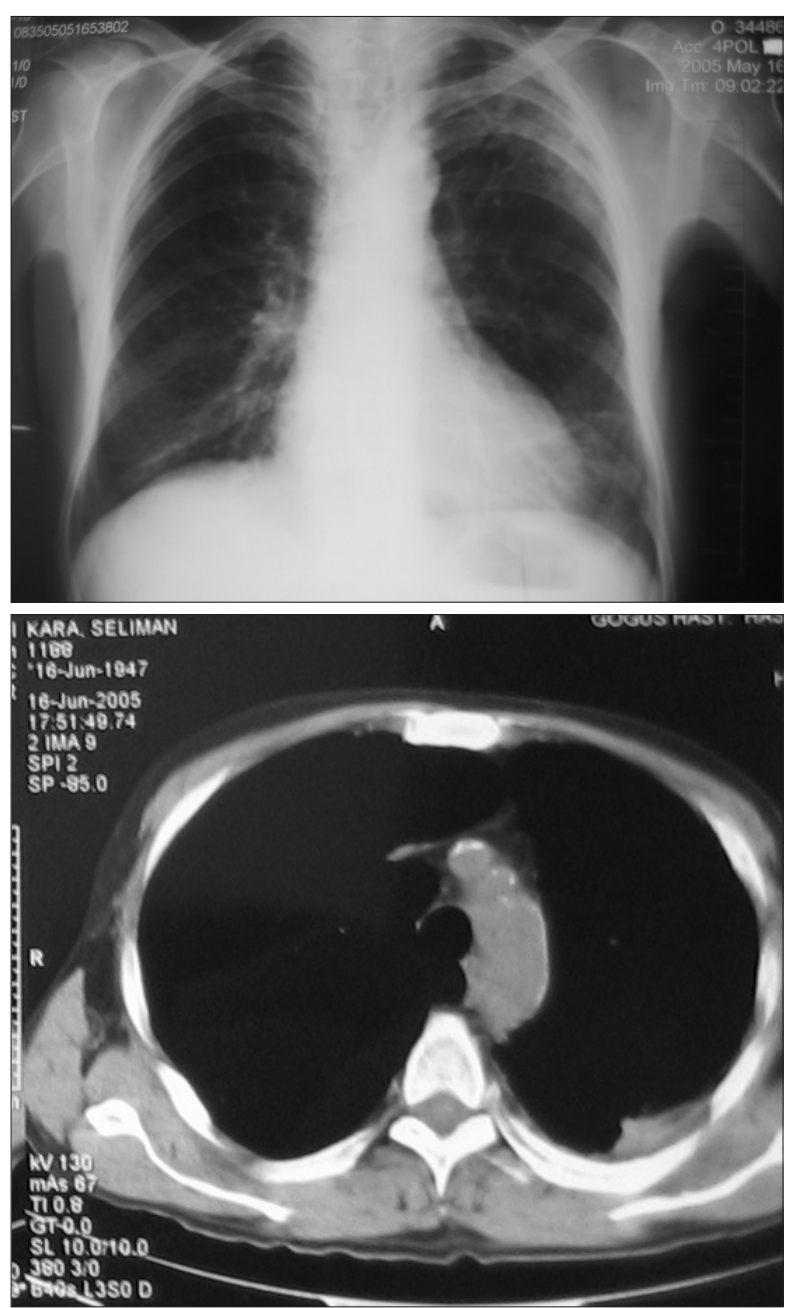

Fig. 6. - At sixth month of the therapy, radiologic recovery in the cold abscess was observed, and fibrotic changes were detected in the lung.

and costal resection even if it is macroscopically normal [3].

Our case underwent 12-month anti-tuberculosis treatment. Follow-up controls were conducted in the first 6 months of the treatment, full response was achieved clinically and partial response was achieved on the pulmonary lesion radiologically. Although it was a case with reduced immune defences and doses of some drugs were lowered due to chronic renal failure, the treatment was successful in our case. We believe that the abscess excision conducted before the administration of the medical treatment contributed to the healing of the disease.

Consequently, "Empyema necessitatis" should be among the preliminary diagnoses when there is a soft tissue swelling on the chest wall without inflammatory findings in patients with reduced immune defences along with history of tuberculosis, or with symptoms that suggest of tuberculosis infection.

\section{References}

1. Hussein MM, Mooij JM, Poujouleh H. Tuberculosis and chronic renal disease. Semin Dial 2003: 16; 38-44.

2. Hsu HS, Wang LS, Wu YC, Fahn HJ, Huang MH. Management of primary chest wall tuberculosis. Scand $J$ Thorac Cardiovasc Surg 1995; 29: 119-23. 
3. Paik CH, Chung KY, Kang JH, Maeng DH. Surgical treatment of tuberculosis cold abscess of the chest wall. Yonsei Med J 2002; 43: 309-149.

4. Davidson PT, Fernandez E. Kemik ve eklem Tüberkülozu. D chlossberg (ed) Tüberküloz'da. İstanbul: Bilimsel ve Teknik yayınlarıçeviri Vakfı; 1995: 29-39.

5. Chung SY, Yang I, Bae SH, Lee Y, Park HJ, Kim HH, Im JG. Tuberculous abscess in retromammary region: CT findings. J Comput Assist Tomogr 1996; 20: 766-9.

6. Moore DAJ, Lightstone L, Javid B, Friedland JS. High Rates of tuberculosis in end stage renal failure: the impact of international migration. Emerg Infect Dis 2002; 8: 77-8.

7. Öner Eyüboğlu AF, Akçay MS, Arslan H, et al. Extrapulmonary involvement of Mycobacterial infections in dialysis patients. Transplant Proc 1999; 31: 3199-201.

8. Cengiz K. İncreased incidence of tuberculosis infection in dialysis patient. Semin Nephron 1996; 73: 421-4.

9. Fukasawa H, Suzuki H, Kato A, Yamamoto T, Fujigaki Y, Yonemura K, Hishida Tuberculous arthritis mimicking neoplasm in a hemodialysis patient. Am J Med Sci 2001; 322: 373-5.

10. Lepikhin NM, Mudrov VB. Differential diagnosis aspects of computerized tomography in cancer and tuberculosis of the lung. Probl Tuberk 2001; 3: 16-22.

11. İclal I, Bilge BF, Füsun K, et al. Peuropulmonary tuberculosis in patient with end-stage renal disease: Findings on chest radiograghs. Transplant Proc 1993; 31: 1719-20.

12. Iseman MD, Madsen LA. Chronic tuberculous empyema with bronchopleural fistula resulting in treatment failure and progressive drug resistance. Chest 1991; 100: 124-127.

13. Forrest OM, John DB, McGovern TM, Ravishankar S, Slamon NB, Hertzog JH. J Pediatr Surg 2006; 41: 7.

14. Freeman AF, Ben-Ami T, Shulman ST. Streptacoccus pneumoniae empyema necessitatis. Pediatric Infect Dis $J$ 2004; 23: 177-179.

15. Sahn, SA, Iseman, MD. Tuberculous empyema. Semin Respir Infect 1999; 14: 82-87.

16. Faure E, Souilamas R, Riquet M, Chehab A, et al. Cold abscess of the chest wall: A surgical entity? Ann Thorac Surg 1998; 66: 1174-8.

17. Kalac N, Güven SF, Putun ET, Özkan B, Demirağ F. Soft tissue tuberculosis. Eur Respir J 3; 22: 2003: 590s.

18. Seibert AF, Haynes J, Middleton R, et al. Tuberculous pleural effusion: twenty-year experience. Chest 1991; 99: 883-886.

19. Murray JF, Nadel JA. Textbook of respiratory medicine 2nd ed., 1994; 2168-2173 WB Saunders Philadelphia, PA.

20. Sindel EA. Empyema necessitatis. Q Bull Sea View Hosp 1940; 6: 1-49.

21. Iseman MD, Madsen LA. Chronic tuberculous empyema with bronchopleural fistula resulting in treatment failure and progressive drug resistance. Chest 1991; 100: 124-127.

22. Elliot AM, Bernign SE, Iseman MD, et al. Failure of drug penetration and acquisition of drug resistance in chronic tuberculosis empyema. Tuber Lung Dis 1955; 76: 463-467.

23. Raymond F, Levard G, Bataille B. Sacral bone tuberculosis in a 6 year-old child. Arch Pediatr 1994; 1: 489-92.

24. Büyüksirin M, Polat G, Yüncü G, Küdür G, Ermete S, Tibet G. Gögüü duvarında tüberküloz soğuk absesi. İzmir Gögüis Hastanesi Dergisi 2004; 18: 93-6.

25. Çakan A, Ercan S, Özsöz A, Dinç ZA, Kumcuoğlu Z. Vertebra, kosta ve yumuşak doku tüberkülozu (olgu sunumu). İzmir Gögüs Hastanesi Dergisi 1997; 9: 29-36.

26. Chen CH, Shih JF, Wang LS, Perng RP. Tuberculous subcutaneous abscess: an analysis of seven cases. $T u$ bercle Lung Dis 1996; 77: 184-7.

27. Porcel JM, Madroñero AB, Bielsa S. Tuberculosis Empyema Necessitatis. Resp 2004; 71: 191.

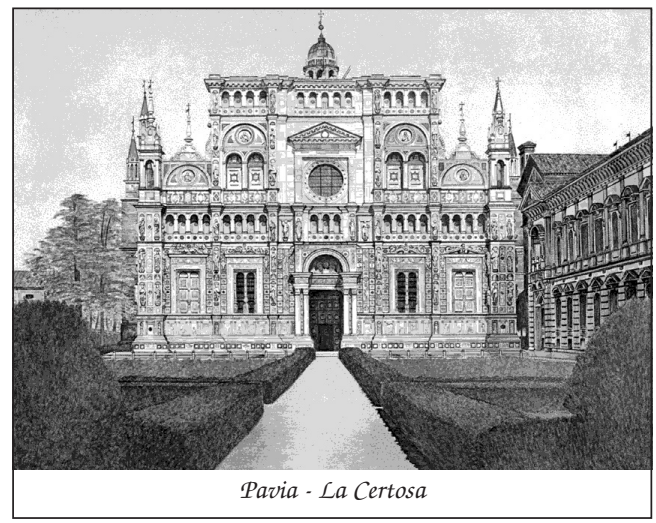

